Info Artikel

Diterima : 09 April 2020

Disetujui : 13 Juli 2020

Dipublikasikan : 20 Juli 2020

\title{
Peningkatan Kemampuan Menulis Teks Deskripsi Siswa Kelas VII SMP Berdasarkan Level Pemula Menggunakan Teknik Retrival Jaringan Semantik
}

\author{
Tobias Nggaruaka ${ }^{1}$, Agus Kichi Hermansyah ${ }^{2} \bowtie$ \&anti Monika $^{3}$ \\ Universitas Musamus, Indonesia \\ 2aguskichi@unmus.ac.id
}

\begin{abstract}
This research was conducted for seventh grade students of YPPGI Geradus Adii Merauke. Based on the observation, it was found that students' ability in writing descriptive text at grade VII is still low. For that reason, the purpose of this study is to improve the ability to write descriptive text using semantic network retrival techniques. This study employed qualitative research with a class action research (CAR) design. The research design used includes: observation, analysis, planning, implementation, reflection, and evaluation. This research data is in the form of process data and learning assessment result data. The data was collected through observations, interviews, results of actions, field notes, and documentation. The results showed that the learning achievement in the first cycle of the first meeting was $28.57 \%$. While at the second meeting of the first cycle learning outcomes has increased to $57.14 \%$. Then, the learning outcomes in the second cycle of the first meeting increased to $85.71 \%$. Whereas at the second meeting the second cycle increased to $100 \%$ with minimal completeness criteria.
\end{abstract}

Keywords: improving, writing description text, semantic network retrival technique

Abstrak : Kemampuan menulis teks deskripsi siswa kelas VII SMP YPPGI Geradus Adii Merauke masih rendah. Berdasarkan permasalahan tersebut tujuan penelitian ini adalah meningkatkan kemampuan menulis teks deskripsi dengan menggunakan teknik retrival jaringan semantik. Penelitian ini menggunakan jenis penelitian kualitatif dengan rancangan penelitian tindakan kelas (PTK). Rancangan penelitian yang digunakan meliputi: observasi, analisis, perencanaan, pelaksanaan, refleksi, dan evaluasi. Data penelitian ini adalah berupa data proses dan data hasil penilaian pembelajaran. Data tersebut dikumpulkan dengan menggunakan instrumen penelitian yaitu; hasil pengamatan, wawancara, hasil tindakan, catatan lapangan, dan dokumentasi. Hasil penelitian menunjukkan bahwa pembelajaran pada siklus I pertemuan I dengan presentasi 28,57\%. Sedangkan pada pertemuan II siklus I hasil pembelajaran meningkat menjadi 57,14\%. Hasil pembelajaran pada siklus II pertemuan I meningkat menjadi

Sitasi Artikel:

Nggaruaka, T., Hermansyah, A., \& Monika, S. (2020). Peningkatan Kemampuan Menulis Teks Deskripsi Siswa Kelas VII SMP Berdasarkan Level Pemula Menggunakan Teknik Retrival Jaringan Semantik. Disastra: Jurnal Pendidikan Bahasa dan Sastra Indonesia, 2(2), 154-163. doi:http://dx.doi.org/10.29300/disastra.v2i2.3039 
$85,71 \%$. Sedangkan pada pertemuan II siklus II meningkat menjadi $100 \%$ dengan kriteria ketuntasan minimal.

Kata Kunci : peningkatan, menulis teks deskripsi, teknik retrival jaringan semantik

\section{Pendahuluan}

Pembelajaran bahasa Indonesia di sekolah merupakan salah satu mata pelajaran wajib yang diajarkan pada semua jenjang pendidikan. Tujuan pengajaran bahasa di setiap jenjang pendidikan adalah untuk meningkatkan kemampuan bahasa yang meliputi empat keterampilan yaitu: menyimak, berbicara, membaca, dan menulis. Untuk mengembangkan kemampuan tersebut dalam pembelajaran bahasa siswa dilatih untuk meningkatkan keterampilan bahasa yang dilakukan secara prosedural dan sistematis dengan melibatkan siswa secara langsung dalam proses pembelajaran (Hermansyah, Harsiwi, Purwanty, \& Tembang, 2018). Dalam hal ini guru menjadi motivator, pembimbing, pengarah, dan sebagai fasilitator dalam aktivitas pembelajaran di kelas (Nggaruaka, 2017).

Pengembangan kemampuan menulis melibatkan banyak jenis kompetensi dan keterampilan dalam menggunakan strukturstruktur linguistik, sosiolinguistik dan wacana (Martutik, 2012). Tugas menulis biasanya bermacam-macam bentuknya, mengisi formulir, sampai menyajikan informasi ataupun penggunaan bahasa secara imajinatif (Ghazali, 2013). Menulis merupakan salah satu sarana menyampaikan informasi, sehingga di dalam pembelajaran bahasa keterampilan menulis dikategorikan sebagai salah satu dari 4 keterampilan yang sulit. Untuk membelajarkan keterampilan bahasa anak, sesungguhnya berdasarkan tahapan pembelajaran mulai dengan tahap menyimak, berbicara, membaca dan menulis
(Martutik, 2012). Dengan demikian dikatakan keterampilan menulis merupakan keterampilan bahasa yang kompleks.

Dengan adanya tingkat kompleksitas keterampilan menulis, guru diharapkan membuat siswa menjadi lebih sadar akan strategi menulis mereka dengan cara memberikan kegiatan menulis dengan berbagai macam tujuan yang berbeda (Riwu \& Janjaan, 2017). Dalam hal ini peranan guru sangat dibutuhkan dalam memberikan pemahaman dan tuntutan serta memberikan makna pembelajaran kepada siswa dengan berbagai simulasi yang membantu siswa dalam hal menulis (Ibda, 2020). Pembelajaran menulis telah diberikan sejak jenjang sekolah dasar yang menjadi dasar dalam penerimaan keterampilan tersebut, kemudian dilanjutkan pada tingkat SMP.

Pengajaran keterampilan menulis di tingkat SMP diharapkan memberikan kontribusi yang berarti bagi siswa, terutama dalam pengembangan intelektualitas siswa. Proses pembelajaran menulis tidak terlepas dari tuntutan dan kasih sayang seorang guru, sehingga ketika ditanya apa peranan guru bagi siswa, maka jawabanya adalah guru sebagai motivator guru sebagai inovator, guru sebagai pembimbing, dan guru sebagai pengelolah kelas (Hermansyah, 2016). Pengajaran bahasa (menulis teks deskripsi) berdasarkan prosedur bagi kebanyakan guru merupakan salah satu cara yang sulit, sehingga di dalam proses pembelajaran bahasa (menulis) guru cenderung kepada kegiatan menulis tanpa prosedur. Artinya ketika penelitian ini dilakukan maka di dalam proses pembelajaran peneliti 
menggunakan teknik retrival yaitu dengan membantu siswa untuk melakukan kegiatan pembelajaran secara prosedural yaitu kegiatan penomoran daftar kata, mengisian teks rumpang, dan pengembangan teks deskripsi. Sesungguhnya teknik retrival adalah sebuah teknik untuk memanggil kembali semua informasi yang tersimpan baik di dalam memori jangka pendek maupun jangka panjang. Sehingga ketika mengembangkan teks deskripsi siswa tidak kesulitan karena siswa telah memiliki skemata sebelumnya. Dalam hal ini siswa meretrif informasi-informasi dan ditungkan dalam bentuk tulisan. Nggaruaka,dkk, (2019) siswa akan mampu meretrif kosakata atau informasi berdasarkan pengetahua yang siswa muiliki.

Menulis merupakan salah satu keterampilan yang digunakan oleh penulis untuk mengkomunikasikan berbagai macam pesan kepada pembaca yang berbedaberbeda merupakan sesuatu yang baru bagi kebanyakan guru bahasa saat ini (Ghazali, 2013). Untuk membelajarkan keterampilan bahasa lebih khusus keterampilan menulis teks deskripsi memerlukan pemahaman bagaimana menggabungkan komponenkomponen linguistik (pengetahuan tentang kosakata, tata bahasa, ortografi, struktur genre) agar dapat menghasilkan sebuah teks (Dardjowidjojo, 2010). Di dalam kegiatan menulis seorang penulis dituntut untuk sekadar menulis apa yang ia ingin tulis, tetapi diharapkan seorang penulis sesungguhnya harus mempertimbangkan atau menduga-duga apa yang ia ingin tulis, apa yang ia ketahui dan apa yang pembaca akan diketahui ketika membaca hasil tulisannya (Satinem, 2015). Berdasarkan pernyataan di atas maka dapat disimpulkan bahwa kegiatan menulis merupakan salah satu kegiatan yang menuntut kreativitas, kejelian, kesabaran dalam menuangkan ide atau pesan kepada pembaca.

Diharapkan kepada guru untuk mengajarkan keterampilan bahasa khususnya keterampilan menulis sejak dini. Selain itu untuk membentuk karakter siswa dengan adanya kegiatan menulis sejak dini sudah banyak penelitian yang menyarankan seperti Scott 1992 dalam Ghazali (Ghazali, 2013) menyarankan agar siswa diajarkan menulis sejak awal proses belajar. Untuk itu guru diharapkan mengembangkan intelektualitas siswa dalam berbagai situasi belajar terlebih khusus dalam kegiatan menulis berdasarkan proses atau level.

Berdasarkan observasi yang dilakukan oleh peneliti pada siswa kelas VII SMP YPPGI Geradus Adi Merauke. Beberapa hal ditemukan antara lain; (1) siswa belum terampil dalam menulis teks deskripsi, (2) siswa sulit mengungkapkan ide dan gagasan dalam menulis teks deskripsi, (3) siswa belum memahami tahapan menulis teks deskripsi dan belum mengetahui struktur teks deskripsi, (4) di dalam kegiatan menulis teks deskripsi guru lebih mementingkan hasil dibandingkan tahapan atau proses.

\section{Metode Penelitian}

Penelitian ini merupakan penelitian kualitatif. Dinyatakan bersifat kualitatif karena berupaya menghasilkan data verbal maupun nonverbal yang secara potensial dapat menghasilkan makna dan informasi yang sesuai dengan tujuan penelitian. Penggunaan pendekatan kualitatif karena mengandalkan data berupa teks dan gambar, dan memiliki langkah-langkah dalam menganalisis data yang bersumber dari 
strategi-strategi yang digunakan dalam penelitian (Creswell, 2013). Selain itu juga, dipertegas bahwa penelitian kualitatif merupakan penelitian interpretatif, yang di dalam penelitiannya peneliti terlibat dalam pengalaman yang berkelanjutan dan terus menerus dengan para partisipan (Creswell, 2013). Rancangan penelitian ini adalah penelitian deskriptif kualitatif. Karena data yang diperoleh dalam penelitian ini, selanjutnya dianalisis secara induktif pada saat penelitian maupun setelah penelitian berlangsung.

Data yang diperoleh dalam penelitian ini, selanjutnya dianalisis secara induktif pada saat penelitian maupun setelah penelitian berlangsung. Selanjutnya hasil analisis data disajikan dalam deskripsi fenomena bukan perhitungan angka-angka. Hal ini sejalan dengan karakteristik penelitian kualitatif yang terdiri dari enam bentuk, yaitu (1) latar penelitian sebagai sumber pengambilan data bersifat alamiah, (2) bersifat deskriptif, (3) bersifat induktif, (4) peneliti menjadi instrumen kunci, dan (5) menekankan pada proses selain hasil, serta (6) makna menjadi tekanan utama (Bogdan \& Biklen, 1990).

Langkah awal dalam penelitian ini dimulai dengan kegiatan observasi terhadap pelaksanaan kegiatan belajar mengajar. Dari hasil observasi sebagai langkah awal, kemudian dilakukan analisis hasil observasi tersebut. Persoalan pembelajaran di kelas dipertimbangkan sebagai persoalan yang perlu ditingkatkan dengan melakukan inovasi pembelajaran yaitu penerapan teknik retrival pada proses pembelajaran menulis (level pemula). Hasil penerapan teknik retrival dalam pembelajaran menulis pada siswa SMP YPPGI Geradus Adii Merauke selanjutnya akan didiskusikan dengan guru sebagai langkah inovasi dan dapat diterapkan dalam pembelajaran khususnya pembelajaran menulis teks deskripsi.

\section{Hasil dan Pembahasan \\ Deskripsi Siklus I Pertemuan I}

Penelitian yang dilakukan di SMP YPPGI Geradus Adii Merauke dilakukan dalam dua siklus. Kegiatan pembelajaran siklus I dilakukan II pertemuan dan siklus II dilakukan dalam II pertemuan. Berdasarkan hasil penelitian pada siklus I dengan jumlah subjek penelitian yaitu 7 siswa. Dalam kegiatan pembelajaran dilakukan secara tahap sebagai wujud pembelajaran berbasis proses. Ada pun hasil pmbelajaran siklus I perteman I sebagai berikut:

Tabel 1. Hasil Pembelajaran Tahap penomoran Siklus I Pertemuan I

\begin{tabular}{|c|c|c|}
\hline $\begin{array}{c}\text { Siswa yang } \\
\text { berh- } \\
\text { asil }(\%) \\
\end{array}$ & $\begin{array}{c}\text { Siswa yang } \\
\text { tidak berhasil } \\
(\%)\end{array}$ & $\begin{array}{c}\text { Keterangan } \\
(\%)\end{array}$ \\
\hline $\begin{array}{l}3 \text { siswa } \\
\text { melakukan } \\
\text { kegiatan } \\
\text { penomoran } \\
\text { daftar kosakata } \\
\text { denngan } \\
\text { tingkat } \\
\text { ketuntasan } \\
42,85 \% \text { (cukup } \\
\text { baik) }\end{array}$ & $\begin{array}{l}4 \text { siswa tidak } \\
\text { dapat } \\
\text { melakukan } \\
\text { kegiatan } \\
\text { penomoran } \\
\text { pada daftar } \\
\text { kata dengan } \\
\text { presentasi } \\
57,14 \% \\
\text { (kurang) }\end{array}$ & $\begin{array}{l}\text { Dari hasil } \\
\text { belajar pada } \\
\text { siklus I } \\
\text { Pertemuan I } \\
\text { tahap } \\
\text { penomoran } 4 \\
\text { siswa m } \\
\text { elakukan } \\
\text { penomoran } \\
\text { presentasi } \\
57,14 \% \text { ) } \\
\text { (kurang) }\end{array}$ \\
\hline
\end{tabular}

Siklus I pertemuan I kegiatan pengisian teks rumpang dan pengembangan teks deskripsi dapat dilihat pada tabel 2. 
Tabel 2. Hasil belajar Siklus I Pertemuan

II tahap pengisian teks rumpang dan pengembangan teks deskripsi

\begin{tabular}{lll}
\hline \multicolumn{1}{c}{$\begin{array}{c}\text { Siswa yang } \\
\text { Berhasil (\%) }\end{array}$} & $\begin{array}{c}\text { Siswa yang tidak } \\
\text { berhasi \% }\end{array}$ & $\begin{array}{l}\text { Keterangan } \\
(\%)\end{array}$ \\
\hline 2 siswa mampu & 5 siswa tidak & Berdasarka \\
mengisi teks & dapat mengisi teks & n hasil \\
rumpang dan & rumpang dan & penelitian \\
mengembangkan & mengembangkan & pada siklus \\
teks deskripsi & teks deskripsi & I \\
berdasarkan & dengan presentasi & pertemuan \\
struktur & $71,42 \%$ (kurang & I sebanyak \\
pengembangan & baik) & 5 siswa \\
teks deskripsi & & belum \\
dengan kriteria & & KKM, \\
ketuntasan & & sedangkan \\
28,57\% (Sangat & & 2 \\
baik) & & mencapai \\
& & KKM. \\
\hline
\end{tabular}

\section{Deskripsi Siklus I Pertemuan II}

Berdasarkan hasil penelitian pada siklus I pertemuan II dengan jumlah subjek penelitian yaitu 7 siswa. Dalam kegiatan pembelajaran dilakukan secara bertahap sebagai wujud pembelajaran berbasis proses. Ada pun uraian hasil belajar sebagai berikut:

\begin{tabular}{|c|c|c|}
\hline $\begin{array}{l}\text { Siswa yang } \\
\text { berh- } \\
\text { asil (\%) }\end{array}$ & $\begin{array}{c}\text { Siswa yang } \\
\text { tidak berhasil } \\
(\%)\end{array}$ & Keterangan (\%) \\
\hline $\begin{array}{l}5 \text { siswa } \\
\text { melakukan } \\
\text { kegiatan } \\
\text { penomoran } \\
\text { pada daftar } \\
\text { kosakata } \\
\text { dengan } \\
\text { presentasi } \\
71,42 \% \text { (baik) }\end{array}$ & $\begin{array}{l}\text { s siswa tidak } \\
\text { dapat } \\
\text { melakukan } \\
\text { kegiatan } \\
\text { penomoran } \\
\text { dengan } \\
\text { presentasi } \\
28,57 \% \\
\text { (kurang) }\end{array}$ & $\begin{array}{l}\text { Hasil } \\
\text { pembelajaran } \\
\text { Siklus I } \\
\text { Pertemuan II } 2 \\
\text { Siswa Belum } \\
\text { KKM pada } \\
\text { tahap kegiatan } \\
\text { penomoran }\end{array}$ \\
\hline
\end{tabular}

Siklus I Pertemuan II tahap kegiatan pengisian teks rumpang dan pengembangan teks deskripsi dapat dilihat pada tabel di bawah ini:
Tabel 4. Hasil belajar tahap pengembangan teks desripsi Siklus I Pertemuan II

\begin{tabular}{|c|c|c|}
\hline $\begin{array}{l}\text { Siswa yang } \\
\text { Berhasil }(\%)\end{array}$ & $\begin{array}{c}\text { Siswa yang } \\
\text { Tidak Berhasil } \\
(\%)\end{array}$ & $\begin{array}{c}\text { Keterangan } \\
(\%)\end{array}$ \\
\hline $\begin{array}{l}4 \text { siswa mampu } \\
\text { pengisian teks } \\
\text { rumpang dan } \\
\text { pengembangan } \\
\text { teks deskripsi } \\
\text { berdasarkan } \\
\text { struktur } \\
\text { pengembangan } \\
\text { teks deskripsi } \\
\text { dengan } \\
\text { presentasi } \\
57,14 \% \text { (Sangat } \\
\text { baik) }\end{array}$ & $\begin{array}{l}3 \text { siswa dapat } \\
\text { mengisi teks } \\
\text { rumpang dan } \\
\text { mengembangka } \\
\text { n teks deskripsi } \\
\text { namun tidak } \\
\text { sesuai dengan } \\
\text { struktur dan } \\
\text { tindak detail } \\
\text { dengan } \\
\text { presentasi } 42 \text {, } \\
85 \% \text { (kurang } \\
\text { baik) }\end{array}$ & $\begin{array}{l}\text { Berdasarkan } \\
\text { hasil penelitian } \\
\text { pada siklus I } \\
\text { pertemuan II } 4 \\
\text { siswa } \\
\text { mencapai } \\
\text { KKM } \\
\text { sedangkan } \\
\text { sebanyak } 3 \\
\text { siswa belum } \\
\text { KKM, }\end{array}$ \\
\hline
\end{tabular}

\section{Deskripsi Siklus II Pertemuan I}

Berdasarkan hasil penelitian tahap penomoran, pengisia teks rumpang dan pengembangan teks deskripsi. Sebagai berikut.

\section{Tabel 5. Hasil Belajar Siklus II} Pertemuan I

\begin{tabular}{|c|c|c|}
\hline $\begin{array}{c}\text { Siswa yang } \\
\text { Berhasil }(\%)\end{array}$ & $\begin{array}{c}\text { Siswa yang } \\
\text { Tidak Berhasil } \\
(\%)\end{array}$ & Keterangan (\%) \\
\hline $\begin{array}{l}6 \text { sisswa } \\
\text { berhasil } \\
\text { menomori } \\
\text { daftar } \\
\text { kosakata, } \\
\text { mengisi teks } \\
\text { rumpang, dan } \\
\text { mengembang } \\
\text { akan teks } \\
\text { deskrupsi } \\
\text { dengan } \\
\text { presentasi } 85, \\
71 \% \text { (sangat } \\
\text { baik) }\end{array}$ & $\begin{array}{l}1 \text { siswa mampu } \\
\text { mengisi teks } \\
\text { rumpang dan } \\
\text { mengembangka } \\
\mathrm{n} \text { teks deskripsi } \\
\text { tanpa } \\
\text { memperhatikan } \\
\text { struktur teks } \\
\text { deskripsi } \\
\text { dengan } \\
\text { presentasi } \\
14,28 \% \\
\text { (kurang) }\end{array}$ & $\begin{array}{l}6 \text { siswa lainnya } \\
\text { mampu mengisi } \\
\text { teks rumpang } \\
\text { dan } \\
\text { mengembangkan } \\
\text { teks deskripsi } \\
\text { berdasarkan } \\
\text { struktur } \\
\text { pengembangan } \\
\text { teks deskripsi } \\
\text { dengan } \\
\text { presentasi } \\
85,71 \% \text { (Baik) } \\
\text { Keberhasilan } \\
\text { pada siklus II } \\
\text { pertemuan I } \\
\text { sebanyak } 6 \text { siswa } \\
\text { mencapai KKM, } \\
\text { sedangkan } 1 \\
\text { yang tidak } \\
\text { mencapai tingkat } \\
\text { KKM. }\end{array}$ \\
\hline
\end{tabular}




\section{Deskripsi Siklus II Pertemuan II}

Hasil penelitian pada siklus II pertemuan II dengan jumlah subjek penelitian yaitu 7 siswa. Ada pun uraian hasil belajar sebagai berikut.

Tabel 6. Hasil Pembelajaran Siklus II Pertemuan II

\begin{tabular}{|c|c|c|}
\hline $\begin{array}{c}\text { Siswa yang } \\
\text { Berhasil }(\%)\end{array}$ & $\begin{array}{c}\text { Siswa yang } \\
\text { Tidak Berhasil } \\
(\%)\end{array}$ & $\begin{array}{c}\text { Keterangan } \\
(\%)\end{array}$ \\
\hline $\begin{array}{l}\text { Dalam kegiatan } \\
\text { pembelajaran } \\
\text { tahap } \\
\text { penomoran dan } \\
\text { mengisi teks } \\
\text { rumpang } 7 \\
\text { siswa berhasil } \\
\text { dengan } \\
\text { presentasi } \\
100 \% \text { dengan } \\
\text { tingkat } \\
\text { ketuntasan } \\
\text { sangat baik. }\end{array}$ & $\begin{array}{l}7 \text { siswa mampu } \\
\text { mengembangka } \\
\mathrm{n} \text { teks deskripsi } \\
\text { berdasarkan } \\
\text { struktur } \\
\text { pengembangan } \\
\text { teks dengan } \\
\text { presentasi 100\% } \\
\text { (sangat baik }\end{array}$ & $\begin{array}{l}\text { Dengan } \\
\text { demikian } \\
\text { tingkat } \\
\text { keberhasilan } \\
\text { pada siklus II } \\
\text { pertemuan II } \\
\text { sebanyak } 7 \\
\text { siswa } \\
\text { mencapai } \\
\text { KKM dengan } \\
\text { presentasi } \\
\text { 100\% }\end{array}$ \\
\hline
\end{tabular}

\section{Pembahasan}

Berdasarkan data hasil penelitian yang dilakukan dalam dua siklus. Setiap siklus dilakukan dua kali pertemuan. Pada siklus I pertemuan I kegiatan penomoran daftar kosakata denngan tingkat ketuntasan $42,85 \% \quad 4$ siswa tidak dapat melakukan kegiatan penomoran pada daftar kata dengan presentasi 57,14\% (kurang), Dari hasil belajar pada siklus I pertemuan I tahap penomoran 4 siswa melakukan penomoran presentasi 57,14\%) (kurang).

Hasil belajar siklus I pertemuan I kegiatan pengisian teks rumpang dan pengembangan teks deskripsi 2 siswa mampu mengisi teks rumpang dan mengembangkan teks deskripsi berdasarkan struktur pengembangan teks deskripsi dengan kriteria ketuntasan 28,57\% (Sangat baik). Sedangkan 5 siswa tidak dapat mengisi teks rumpang dan mengembangkan teks deskripsi dengan presentasi $71,42 \%$ (kurang baik). Berdasarkan hasil penelitian pada siklus I pertemuan I sebanyak 5 siswa belum KKM, sedangkan 2 siswa mencapai KKM.

Hasil penelitian pada siklus I pertemuan II menunjukkan 5 siswa melakukan kegiatan penomoran pada daftar kosakata dengan presentasi 71,42\% (baik), 2 siswa tidak dapat melakukan kegiatan penomoran dengan presentasi 28,57\% (kurang), Hasil pembelajaran Siklus I Pertemuan II 2 Siswa Belum KKM pada tahap kegiatan penomoran.

Siklus I Pertemuan II tahap kegiatan pengisian teks rumpang dan pengembangan teks deskripsi sebagai berikut. 4 siswa mampu pengisian teks rumpang dan pengembangan teks deskripsi berdasarkan struktur pengembang an teks deskripsi dengan presentasi 57,14\% (Sangat baik), 3 siswa dapat mengisi teks rumpang dan mengembangkan teks deskripsi namun tidak sesuai dengan struktur dan tindak detail dengan presentasi 42, $85 \%$ (kurang baik). Berdasarkan hasil penelitian pada siklus I pertemuan II 4 siswa mencapai KKM sedangkan sebanyak 3 siswa belum KKM.

Berdasarkan hasil penelitian tahap penomoran, pengisia teks rumpang dan pengembangan teks deskripsi siklus II pertemuan I sebagai berikut: 6 siswa berhasil mengisi teks rumpang dengan presentasi $85,71 \%$ (sangat baik), 1 siswa mampu mengisi teks rumpang dan mengembangkan teks deskripsi tanpa memperhatikan struktur teks deskripsi dengan presentasi 14,28\% (kurang), 6 siswa lainnya mampu mengisi teks rumpang dan 
mengembangkan teks deskripsi berdasarkan struktur pengembangan teks deskripsi dengan presentasi $85,71 \%$. (Baik) Keberhasilan pada siklus II pertemuan I sebanyak 6 siswa mencapai KKM, sedangkan 1 yang tidak mencapai tingkat KKM.

Hasil penelitian pada siklus II pertemuan II sebagai berikut: Dalam kegiatan pembelajaran tahap penomoran dan mengisi teks rumpang 7 siswa berhasil dengan presentasi $100 \%$ dengan tingkat ketuntasan sangat baik, 7 siswa mampu mengembangkan teks deskripsi berdasarkan struktur pengembangan teks dengan presentasi $100 \%$ (sangat baik, Dengan demikian tingkat keberhasilan pada siklus II pertemuan II sebanyak 7 siswa mencapai KKM.

Temuan penelitian di atas menunjukkan bahwa menulis merupakan sebuah proses yang memerlukan sebuah keterampilan. Menulis merupakan kegiatan atau proses menyampaikan pesan secara singkat pada pihak lain. Artinya aktivitas menulis sebagai kegiatan penyampaian pesan atau isi tulisan, saluran atau media tulisan dan pembaca sebagai penerima pesan (Nur, Nggaruaka, \& Hermansyah, 2019). Sebagai suatu keterampilan berbahasa menulis merupakan keterampilan yang kompleks karena penulis dituntut dapat menyusun dan mengorganisasikan tulisannya serta menuangkan dalam formulasi ragam bahasa tulis dan konvensi penulisan lainnya. Dengan demikian menulis hakikatnya adalah menuangkan ide atau gagasan yang dimiliki seseorang melalui bahasa tulis (Betaubun, Hermansyah, Sumarsono, Purwanty, \& Tembang, 2018).
Pengetahuan yang dimiliki oleh setiap orang berbeda-beda sehingga hasil pikiran yang dituangkan berdasarkan kognisi dan pengalaman pribadi setiap orang dan tulisan yang dihasilkan beragam. Ghazali menyatakan bahwa menulis merupakan proses mengintegrasikan ide-ide baru, merevisi ide-ide yang sudah tertuang dalam tulisan dan rekonstruksi kerangka dasar dari tulisan (Ghazali, 2013). Kegiatan menulis juga mengharuskan penulis untuk memeriksa sendiri sejauh mana kejelasan uraian dan logika dari tulisan. Lebih lanjut Ghazali menyatakan bahwa kemampuan menulis melibatkan banyak kompetensi dan keterampilan dalam menggunakan strukturstruktur linguistik, sosiolinguistik dan wacana (Ghazali, 2013).

Untuk membelajarkan keterampilan menulis kepada siswa tidaklah mudah, perlu desain, perencanaan yang matang dan proses pemilihan metode, teknik dan pendekatan yang tepat, sehingga tujuantujuan yang ingin dicapai dalam proses pembelajaran dapat tercapai. Sebagaimana dikatakan oleh Masnia dalam Nggaruaka bahwa menulis adalah proses berpikir yang terdiri atas serangkaian tahapan dikaitkan dengan pembelajaran (Nggaruaka, 2017). Menulis sebagai proses memberikan kesempatan kepada siswa untuk memperoleh bimbingan dari guru, sehingga proses pembelajaran menulis dapat tercapai sebagaimana diharapkan. Dengan adanya bimbingan dari guru secara tidak langsung siswa terbantu dalam peningkatan keterampilan berbahasa. Ur menyatakan menulis merupakan kegiatan mengekspresikan ide, di dalam menyampaikan pesan kepada pembaca (Ur, 1996). 
Ide yang disampaikan berdasarkan argumen penulis dan ide yang ingin disampaikan perlu dibantu dengan memperhatikan beberapa aspek penulisan dan juga beberapa aspek formal. Aspek formal yang dimaksud adalah kerapian dalam menulis, penggunaan ejaan, dan penggunaan tanda baca, penggunaan gramatikal, dan penggunaan kosakata secara selektif. Peningkatan keterampilan menulis merupakan harapan dalam bidang pendidikan yang harus ditransformasikan kepada peserta didik sebagai terget pembelajaran. Harapan ini tentu membutuhkan proses yang intensif bagi perkembangan kemampuan keterampilan bahasa anak. Sistem pengajaran menulis tentu akan berhasil ketika didukung perangkat pembelajaran yang memadai (Hermansyah, 2016).

Ada tiga hal terkait dengan menulis sebagaimana dikatakan oleh Ur (Ur, 1996) yaitu: pertama, menulis sebagai sarana. Artinya bahwa menulis secara luas digunakan dalam kursus bahasa sebagai cara mudah untuk mengikut sertakan dengan aspek bahasa yang di dalamnya adalah menulis. Seperti mencatat kosakata baru, menyalin aturan tata bahasa, menulis jawaban dalam membaca, atau mendengarkan pertanyaan pemahaman, lakukan tes tertulis, hanya digunakan sebagai sarana dalam melatih siswa dalam bahasa tertentu. Atau sebagai metode yang efektif yang memberikan informasi mengenai suatu standar dimana guru memeriksa berdasarkan reaksi.

Kedua, menulis sebagai akhir, artinya bahwa aktivitas lain mengambil tujuan utama menulis pribadi atau tingkat makro. Tingkatannya adalah menulis pada tingkat kata atau kalimat (tulisan tangan, atau mengetik, ejaan, tanda baca) dan level mikro yaitu menekankan pada konten dan organisasi. Tugas menulis adalah menyuruh siswa untuk mengekspresikan menggunakan kata-kata sendiri, seperti menceritakan sebuah cerita naratif, atau sebuah surat. Ketiga, sebagai sarana dan akhir adalah semacam kegiatan ketiga untuk menggabungkan tujuan dan hasil belajar menulis dan beberapa keterampilan lain. Seperti merespon tulisan dalam membaca (menggabungkan membaca dan menulis), membaca teks anekdot atau ilustrasi makna idiom (menggabungkan praktik menulis kosa kata).

Secara tegas Ur menyatakan bahwa menulis proses di dalam aplikasi pembelajaran bahasa merupakan kegiatan yang dilakukan untuk membelajarkan keterampilan bahasa kepada pembelajar (Ur, 1996). Ada empat strategi yang disarankan di dalam pembelajaran menulis proses oleh yaitu: (1) individu bertukar-tukar. Para penulis yang berbeda dapat menghasilkan karya yang sama bagus namun secara umum ada perbedaan dalam proses menulis, hal tersebut perlu diperhatikan. Sebagai sarana gunakanlah berbagai strategi dengan memberikan harapan kepada setiap individu untuk mengadakan percobaan dan menemukan satu pengalaman efektif bagi pribadi itu sendiri; (2) menulis adalah suatu bisnis morat-marit.

\section{Simpulan}

Berdasarkan uraian paparan hasil penelitian pada siklus 1 dan II dapat diuraikan pada kegiatan pembelajaran guru memperkenalkan media pembelajaran dengan tujuan mengaktifkan skemata siswa 
dan penggunaan teknik retrival jaringan semantik. Hasil penelitian dan pengolahan data menunjukkan terdapat peningkatan hasil belajar siswa pada proses pembelajaran.

\section{Saran}

Saran dalam penelitian ini adalah bahwa dengan menggunakan teknik retrival jaringan semantik pada level pemula dapat meningkatkan kemampuan menulis teks deskripsi siswa kelas VII SMP Geradus Adii Merauke. Berdasarkan hasil penelitian ini, maka disarankan guru SMP Geradus Adii Merauke dapat menggunakan hasil penelitian ini sebagai sumber ataupun model dalam meningkatkan keterampilan bahasa siswa. Dengan menerapkan model pembelajaran ini lebih ditekankan pada proses dan berdasarkan tahapan pembelajaran. Kepada para guru bahasa untuk dapat menerapkan teknik retrival dalam kegiatan pembelajaran bahasa dan guna meningkatkan keterampilan bahasa siswa.

\section{Daftar Pustaka}

Betaubun, S. L., Hermansyah, A. K., Sumarsono, A., Purwanty, R., \& Tembang, Y. (2018). METODE MIND MAPPING UNTUK MENINGKATKAN KREATIVITAS MENULIS DAN HASIL BELAJAR SISWA PADA MATERI KESEHATAN. Musamus Journal of Primary Education, 001-012. https://doi.org/10.35724/musjpe.v1i1. 843

Bogdan, R. C., \& Biklen, S. K. (1990). Qualitative Research for Education:An Introduction Theory And Methods. London: Allyn and
Bacon, Inc.

Creswell, J. W. (2013). Pendekatan Kualitatif, Kuantitatif, dan Mixed. Yogyakarta: Pustaka Pelajar.

Dardjowidjojo. (2010). Psikolinguistik, Pengantar Pemahaman Bahasa Manusia Edisi Kedua. Jakarta: Yayasan Obor Indonesia.

Ghazali, S. A. (2013). Pembelajaran Keterampilan Berbahasa Dengan pendekatan Komunikatif Interaktif. Bandung: PT. Refika Aditama.

Hermansyah, A. K. (2016). MEDIA PEMBELAJARAN PENGHANTAR BERPOLA PIKIR GLOBAL Instructional Media As Conductor To Global Mindset. Prosiding Seminar Nasional II Tahun 2016, Kerjasama Prodi Pendidikan Biologi FKIP Dengan Pusat Studi Lingkungan Dan Kependudukan (PSLK) Universitas Muhammadiyah Malang Malang, 26 Maret 2016, 198-212.

Hermansyah, A. K., Harsiwi, N. E., Purwanty, R., \& Tembang, Y. (2018, January 30). Increasing Indonesian Language Learning Results Through Reviewing Technique of Observation Result Through The Rotating Trio Exchange Method on Grade VI Students of Elementary School. https://doi.org/10.2991/icss-

18.2018.303

Ibda, H. (2020). Peningkatan Keterampilan Menulis Resensi Buku Ilmiah pada Mahasiswa Melalui Program Satu Semester Satu Resensi (TUTER TENSI). Disastra: Jurnal Pendidikan Bahasa Dan Sastra Indonesia, 2(1), 1-13. https://doi.org/10.29300/DISASTRA. V2I1.1998 
Martutik, R. A. (2012). Menulis Dasar Berbasis Tugas. Malang: Surya Pena Gemilang.

Nggaruaka, T. (2017). Peningkatan Kemampuan Menulis Teks Deskripsi Dengan Menggunaka Teknik Retrival Jaringan Semantik Siswa Kelas Vii Smp Negeri I Kabupaten Merauke Provinsi Papua. Universitas Negeri malang.

Nggaruaka, Hermasyah \& Butarbutar, 2019. Pengenalan Bahasa Daerah Marori Menggunakan Teknik Retrival Jaringan Semantik. P.ISSN 24424544. Vol. 6 No. 2.

Nur, A. S., Nggaruaka, T., \& Hermansyah, A. K. (2019). PEMBUATAN MEDIA PEMBELAJARAN BACA TULIS HITUNG (CALISTUNG) BAGI MASYARAKAT DI DISTRIK ULILIN. Sarwahita, 16(02), 105-115. https://doi.org/10.21009/sarwahita.162 .02

Riwu, L., \& Janjaan, B. J. (2017). Penyimpangan Kaidah Ejaan Bahasa Indonesia Dalam Karangan Deskripsi Siswa Kelas XI IPS 1 Sma YPPK Yoanes XXIII Merauke. Magistra, 4(2), 114-122.

Satinem. (2015). Pendidikan Bahasa Indonesia Sebagai Wahana Pembentuk Karakter Bangsa. Seminar Nasional Bulan Bahasa, 320-330.

Ur, P. (1996). A Course In Language Teaching. Practice And Teori. Cambrige: University Press. 